
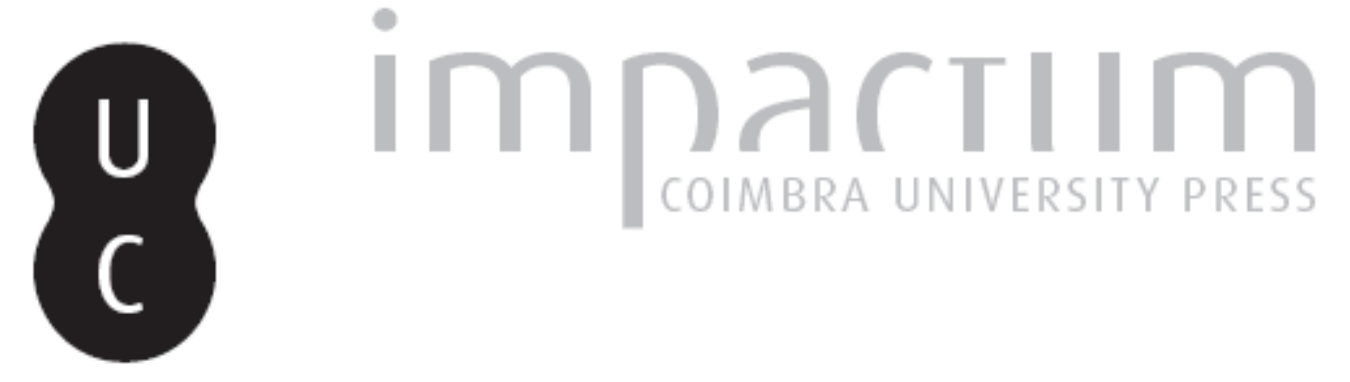

Demographic transition and diversity: assuming Portuguese diversity

Autor(es): $\quad$ Leão, Anabela Costa; Lourenço, Diogo; Cadavez, Pedro; Alberto, Nádia

Publicado por: Centro de Informação Europe Direct de Aveiro; Centro de Estudos

Interdisciplinares do Século XX; Imprensa da Universidade de Coimbra

URL

persistente:

URI:http://hdl.handle.net/10316.2/40942

DOI:

DOI:https://doi.org/10.14195/1647-6336_15-1_3

Accessed : $\quad$ 26-Apr-2023 06:58:24

A navegação consulta e descarregamento dos títulos inseridos nas Bibliotecas Digitais UC Digitalis, UC Pombalina e UC Impactum, pressupõem a aceitação plena e sem reservas dos Termos e Condições de Uso destas Bibliotecas Digitais, disponíveis em https://digitalis.uc.pt/pt-pt/termos.

Conforme exposto nos referidos Termos e Condições de Uso, o descarregamento de títulos de acesso restrito requer uma licença válida de autorização devendo o utilizador aceder ao(s) documento(s) a partir de um endereço de IP da instituição detentora da supramencionada licença.

Ao utilizador é apenas permitido o descarregamento para uso pessoal, pelo que o emprego do(s) título(s) descarregado(s) para outro fim, designadamente comercial, carece de autorização do respetivo autor ou editor da obra.

Na medida em que todas as obras da UC Digitalis se encontram protegidas pelo Código do Direito de Autor e Direitos Conexos e demais legislação aplicável, toda a cópia, parcial ou total, deste documento, nos casos em que é legalmente admitida, deverá conter ou fazer-se acompanhar por este aviso.

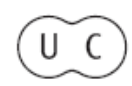


DEBATER

A EUROPA

Supplementum

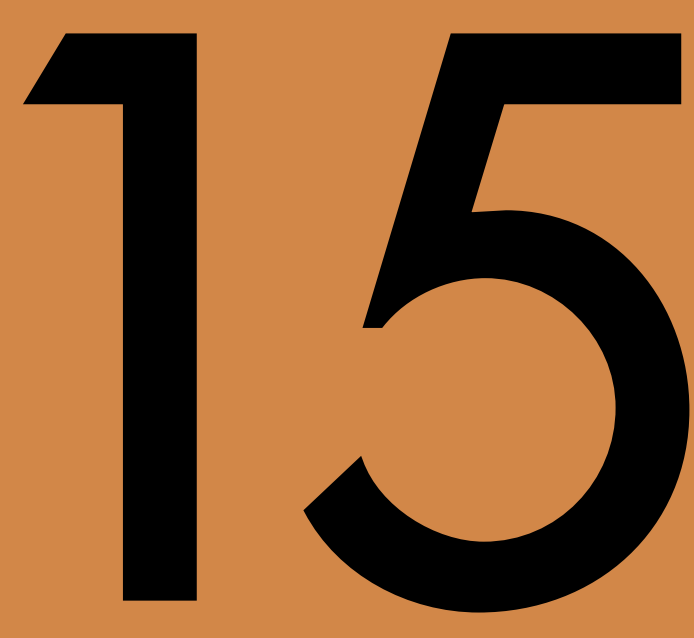

jul-dez 2016

GLOBAL TRENDS 2030:

THE FUTURES OF PORTUGAL

IN AND BEYOND EUROPE 


\title{
Demographic transition and diversity: assuming Portuguese diversity
}

\author{
Anabela Costa Leão, PhD \\ Faculty of Law, University of Porto \\ E-mail: aleao@direito.up.pt
}

Diogo Lourenço, $\mathrm{PhD}$

Centre for Research in Higher Education Policies;

Faculty of Economics, University of Porto

E-mail: dlourenco@fep.up.pt

Pedro Cadavez

Master Student - Faculty of Law, University of Porto

E-mail: pedrocadavez@gmail.com

Nádia Alberto

Master Student - Faculty of Law, University of Porto

E-mail: nadiadias@live.com.pt

The Report Citizens in an Interconnected and Polycentric World. Global Trends $2030^{1}$ (hereinafter, the Report) ${ }^{2}$ sat the mood for reflection throughout the Conference Cycle "Global Trends 2013: the futures of Portugal"” that took place from September 2015 to February 2016 at Serralves, Porto (hereinafter, the Conference Cycle). This text

\footnotetext{
${ }^{1}$ ESPAS Report "Global Trends 2030 - Citizens in an Interconnected and Polycentric World", ed. Álvaro Vasconcelos, 2011. Available at http://www.iss.europa.eu/uploads/media/ESPAS_report_01.pdf $[12 / 20 / 2016]$

${ }^{2}$ The Report "Global Trends 2030", is here closely followed, specially p. $11 \mathrm{ff}$. and $62 \mathrm{ff}$.

${ }^{3}$ Ciclo de Conferências: Tendências Globais 2030: Os Futuros de Portugal, September 2015 to February 2016. More information at http://www.serralves.pt/pt/actividades/ciclo-de-conferencias-tendenciasglobais-2030-os-futuros-de-portugal/.
} 
aims at collecting some reflections on issues, listed bellow, that have been addressed along the Conference Cycle, in dialogue with the above-mentioned Report.

The Report identifies greater human development and reduction of abject poverty as a trend for $2030^{4}$. Even though inequalities are not excluded from the scenario, according to the Report, in the last decade alone, the number of low income countries decreased about 40\% from 66 to 40, and between 2005 and 2010 the number of people living on less than 1.25 USD per day decreased by half a billion ${ }^{5}$. Besides, many projections point out to the convergence of emerging economies with advanced economies in terms of per capita income ${ }^{6}$ and the Report identifies a shift in the center of economic gravity to Asia and South America ${ }^{7}$. It is also noteworthy the expansion of the middle class, whose influence accompanies its size. Its expected growth will be about $50 \%$, from 3.2. billion in 2020 to 4.9 billion in $2030^{8}$.

In spite of the noted progress, weak education systems, the prevalence of epidemic and no epidemic diseases, corruption, climate change and, at the same time, the competition for scarce resources, will continue to pose significant challenges to human development sustainability ${ }^{9}$.

Also according to the Report, State security "will remain a key issue in the period leading up to 2030 "10. Despite major worldwide conflicts do not seem very plausible, wars fuelled by nationalism or by extremist identity demands appear as important challenges ("nationalist politics based on policies of radical affirmation of identity or religion is likely to remain a major security challenge" $\left.{ }^{11}\right)^{12}$. There must also be mentioned the instability resulting from "fragile States" and the tensions associated with the exploration of natural resources ${ }^{13}$.

In this ever-changing world, demographics play a crucial role ${ }^{14}$. In fact, the decrease in both the active and full population of advanced economies, both in absolute terms and compared to emerging economies, will redefine the global economic weight of advanced economies. In what concerns migrations (in the broad sense, including also

\footnotetext{
${ }^{4}$ Report "Global Trends 2030”, p. 15 ff.

5 Report "Global Trends 2030”, p. 62.

${ }^{6}$ Report "Global Trends 2030", p. 62.

${ }^{7}$ Report "Global Trends 2030", p. $61 \mathrm{ff}$.

${ }^{8}$ Report "Global Trends 2030", p. 12.

${ }^{9}$ Report "Global Trends 2030”, p. 15 ff.

${ }^{10}$ Report "Global Trends 2030”, p. 95.

${ }^{11}$ Report "Global Trends 2030", p. 95.

${ }^{12}$ Report "Global Trends 2030", p. 95 ff.

${ }^{13}$ Report "Global Trends 2030", p. 95 ff.

${ }^{14}$ See Report "Global Trends 2030", p. 64 ff.
} 
refugees), contexts as the 2008 economic crisis or the so-called "refugee crisis" (and strong influx of refugees to Europe in recent years, not included in the Report but relevant from the point of view of our goal) affect and shape the movements of people within Europe but also in relation to other countries, placing relevant questions. This was pointed out during the Conference Cycle. Pedro Dallari, in his lecture at the conference of 28 September 2015, mentioned the importance of not merely cyclical but structural approaches ${ }^{15}$. The need for global reflection should not be ignored: as pointed out on the same occasion by SOFIA OLIVEIRA regarding the forced movements of populations, it is not only a local scene in Europe, but a worldwide scenario, that is at stake.

Although none of the trends identified in the above-mentioned Report lean solely on diversity, it was considered appropriate and necessary to discuss, alongside demographic trends, the existence of a global trend towards the affirmation of diversity. Having Portugal as reference, we looked to identify both demographic trends and the diversity of diversity (social, religious, ethno cultural...) in conjunction with the assertion of identities, as well the potential tensions between them and the challenges that (social, political and legal) recognition holds.

Thinking specifically in Portugal, will now attend to the reflexes the identified trends in Portugal aiming outline demographic trends, making use of quantitative data for the purpose.

According to the projections made by the Portuguese National Statistics Institute $(\mathrm{INE})^{16}$, the population residing in Portugal is to decline by about $4.5 \%$ between 2016 and 2030, and about 17\% between 2016 and 2060. Nonetheless, this reduction will not be expected in all age groups. Rather, the population with more than 64 years should increase by about $25 \%$ by 2030 and $40 \%$ by 2060 (Table 1 ).

\footnotetext{
${ }^{15}$ To which we refer. For video-audio record, see http://www.serralves.pt/pt/actividades/ciclo-deconferencias-tendencias-globais-2030-os-futuros-de-portugal/

${ }^{16}$ Instituto Nacional de Estatística, Projeções de População Residente 2012-2060, Informação à comunicação social, March 28, 2014, available at www.ine.pt .
} 
Table 1: Resident population by age

\begin{tabular}{|l|l|l|l|}
\hline & 2016 & 2030 & 2060 \\
\hline$<15$ & 1432067 & 1125823 & 992556 \\
\hline $15-64$ & 6711007 & 5997997 & 4540143 \\
\hline$>64$ & 2178148 & 2731658 & 3042640 \\
\hline Total & 10321222 & 9855478 & 8575339 \\
\hline
\end{tabular}

\section{Source: INE}

This increase is expected higher than the decrease in the number of residents under 15 years old, so the ratio between residents not of working age and residents of working age is expected to increase by 2030, widening in 2060 (Table 2).

Table 2:

\begin{tabular}{|l|lr|lr|l|}
\hline & $\begin{array}{l}\text { Children } \\
\text { person }\end{array}$ & $\begin{array}{r}\text { per } \\
\text { of }\end{array}$ & $\begin{array}{l}\text { Elderly per } \\
\text { person } \quad \text { of } \\
\text { working }\end{array}$ & $\begin{array}{l}\text { Children age } \\
\text { elderly }\end{array}$ & $\begin{array}{r}\text { and } \\
\text { person } \\
\text { working age }\end{array}$ \\
\hline $\mathbf{2 0 1 6}$ & 0.21 & 0.32 & 0.54 \\
\hline $\mathbf{2 0 3 0}$ & 0.19 & 0.46 & 0.64 \\
\hline $\mathbf{2 0 6 0}$ & 0.12 & 0.67 & 0.79 \\
\hline
\end{tabular}

\section{Source: INE}

Meeting this increase projection of the weight of age group above 64 in the resident population, the INE is awaits the fecundity index to remain below the necessary for the renewal of generations. Despite expecting a slight increase in the fertility index of Portuguese women, with an increase in the synthetic fertility rate from 1.24 in 2016 to 1.34 in 2030 and 1.55 in 2060 , these numbers are below the value of 2.1 , considered necessary for the renewal of generations.

According to the same source, the evolution of the resident population is not expected to be equal throughout the Portuguese territory. While the North, Centre and Alentejo are to be expected reductions in resident population above the average, with a 
decrease near or above $5 \%$ and greater than $203020 \%$ by 2060, Lisbon expects a reduction below the national average, of about $1.5 \%$ by 2030 and $5.5 \%$ by 2060 and the Algarve will see its population stable by 2030, and possibly an increase of 3\% by 2060 . It is therefore expected a reconfiguration of the relative weight of the residents of the different regions of the Portuguese territory. (Table 3)

Table 3: Resident population by region NUTS-2

\begin{tabular}{|l|l|l|l|}
\hline NUTS-2 & 2016 & 2030 & 2060 \\
\hline North & $\mathbf{3 6 0 8 3 2 4}$ & $\mathbf{3 4 3 0 0 2 6}$ & $\mathbf{2 7 8 8 2 5 6}$ \\
\hline Center & 2239140 & 2071982 & 1709950 \\
\hline Lisbon & $\mathbf{2 8 0 0 9 6 1}$ & $\mathbf{2 7 5 3 5 5 9}$ & $\mathbf{2 6 4 2 3 3 2}$ \\
\hline Alentejo & $\mathbf{7 2 4 4 5 8}$ & 656339 & $\mathbf{5 3 6 7 3 7}$ \\
\hline Algarve & 441288 & 442885 & 454489 \\
\hline Azores & 247337 & 248093 & 224170 \\
\hline Madeira & 259714 & 252594 & 219405 \\
\hline Total & $\mathbf{1 0 3 2 1} 222$ & $\mathbf{9 8 5 5} 478$ & $\mathbf{8 5 7 5 3 3 9}$ \\
\hline
\end{tabular}

Source: INE

INE's projections also point to an increase in life expectancy at birth in the coming years, both for men and for women. While men will see their life expectancy at birth increased by about $3 \%$ by 2030 and more than $8 \%$ by 2060 , women expect an increase in their life expectancy at birth of around $2.7 \%$ by 2030 and $7.1 \%$ by 2060 . This higher relative increase in life expectancy at birth for male residents is also a greater absolute increase. Thus, the gap between life expectancy at birth of resident women and men residents should decrease from 6.04 years in 2016 to 5.94 years in 2030 and 5.67 years in 2060 (Table 4). 
Table 4: Life expectancy at birth

\begin{tabular}{|l|l|l|l|}
\hline & Men & Women & $\begin{array}{l}\text { Hiatus } \\
(\text { HM })\end{array}$ \\
\hline 2016 & 77.82 & 83.86 & -6.04 \\
\hline 2030 & 80.19 & 86.13 & -5.94 \\
\hline 2060 & 84.21 & 89.88 & -5.67 \\
\hline
\end{tabular}

Source: INE

Concerning population of immigrant origin, according to the data from Pordata ${ }^{17}$, of the 104011000 of residents in Portugal in 2014, 3.8\% corresponds to foreign residents. According to the same source, this figure grew from $0.6 \%$ of the resident population in 1981 to $1.1 \%$ in 1991 and $3.4 \%$ in 2001 . However, there was a decrease of the weight of foreign residents from 2011, when they represented $4.1 \%$ of the resident population in the country.

According to INE, in 2014 about $40 \%$ of foreign residents in Portugal were European nationals, followed by foreigners with African nationality (25.4\%) and then Central or South American (23.3\%) (Table 5). According to this source, in 2014 about $70 \%$ of foreign residents in Portugal came from one of these three: Brazil, EU or PALOP countries (Table 6).

Table 5: Continent of Origin of the Population with Legal Resident Status (2014)

\begin{tabular}{|l|l|l|}
\hline Europe & 153936 & $39.5 \%$ \\
\hline Africa & 98,948 & $25.4 \%$ \\
\hline North America & 3553 & $0.9 \%$ \\
\hline $\begin{array}{l}\text { Central and } \\
\text { South America }\end{array}$ & 90839 & $\mathbf{2 3 . 3 \%}$ \\
\hline Asia & 42492 & $10.9 \%$ \\
\hline Oceania & 309 & $\mathbf{0 . 1 \%}$ \\
\hline stateless & 11 & $\mathbf{0 . 0 \%}$ \\
\hline unknown & 19 & $0.0 \%$ \\
\hline Total & 390,113 & \\
\hline
\end{tabular}

Source: INE

\footnotetext{
${ }^{17}$ Available in http://www.pordata.pt/Portugal/Quadro+Resumo/Portugal-7013 [01/29/2016]
} 
Table 6: Principal Origin of the Population with Legal Resident Status (2014)

\begin{tabular}{|l|l|l|}
\hline $\begin{array}{l}\text { European Union } \\
\mathbf{2 8}\end{array}$ & $\mathbf{1 0 0 , 4 0 7}$ & $\mathbf{2 5 . 7 \%}$ \\
\hline PALOP & 90610 & $23.2 \%$ \\
\hline Brazil & 85,288 & $21.9 \%$ \\
\hline
\end{tabular}

\section{Source: INE}

In fact, according to the annual statistical report from the Immigration and Borders Services (SEF) relating to 2014, Brazilian nationality is the most common among foreign residents ${ }^{18}$. According to the same source, however, there have been observed changes in the relative proportion of the most common nationalities, with China becoming the fifth most relevant, surpassing Angola. Spanish, British and Guinea-Bissau residents have also registered an increase in their relative weight. The annual statistical report from SEF relative to $2015^{19}$, recently published, confirms the downward trend in the number of foreign residents in Portugal, maintaining the Brazilian nationality as the most representative. This report also concludes by the reduction of the potential of demographic growth of foreign resident population ${ }^{20}$.

Attending now to data on the emigrant population, and according to the Statistical Relatório Estatístico 2015 do Observatório da Emigração e Rede Migra, from CIES-IUL, ISCTE-IUL and DGACCP ${ }^{21}$, in 2010 there were more than 2 million Portuguese emigrants (see figure 1.4.). These values make Portugal the 12th country with the highest emigration rate -20.8 of its population (see figure 1.5.).

According to the authors, "Portuguese emigration has been a constant since World War II"22. It has, however, been changing over time. If, up until the 60's, the emigration was usually intercontinental, particularly directed to the Americas and former colonies, since then it has been mainly directed to European countries (p. 21,

\footnotetext{
18 SEF, Relatório Estatístico Anual 2014, available at http://sefstat.sef.pt/Docs/Rifa_2014.pdf [01/29/2016]

19 SEF, Relatório Estatístico Anual 2015, available in https://sefstat.sef.pt/Docs/Rifa_2015.pdf [11/08/2016]

${ }^{20}$ More data at http://www.om.acm.gov.pt/publicacoes-om/publicacoes-estatisticas-om

${ }^{21}$ Pires, Rui Pena, Cláudia Pereira, Joana Azevedo, Inês Espírito Santo, Inês Vidigal e Ana Cristina Ribeiro (2015), Emigração Portuguesa. Relatório Estatístico 2015, Lisboa, Observatório da Emigração e Rede Migra, CIES-IUL, ISCTE-IUL, e DGACCP, available at http://observatorioemigracao.pt/np4/4639.html

${ }^{22}$ Pires, Rui Pena, Cláudia Pereira, Joana Azevedo, Inês Espírito Santo, Inês Vidigal e Ana Cristina Ribeiro (2015), Emigração Portuguesa, p. 21.
} 
para. 2). In fact, the major European destinations between 2000 and 2010 were Switzerland (about 70,000 emigrants), the United Kingdom (55 000), Spain (42,000), France (35 000) and Luxembourg (20 000) (Figure 1.3.). The largest stocks of Portuguese born continue, however, in France (592,281 in 2014), followed by Switzerland (211 451) and the US (177,431) (Table 2.3.).

Besides the change in the destinations, the authors notice that Portuguese emigration has suffered also an increase in its intensity, in particular since the beginning of the millennium, estimating an increase of about 40,000 emigrants in 2001 to about 110000 in 2014 (Table 1.3).

According to the same study (Table 4.2), the Portuguese emigrant is characterized by being in working age (over $60 \%$ of the total migrant stock), to reside for more than 10 years abroad (over $80 \%$ ), and by having a low or very low level of qualifications (over 62\% had at best, in 2011, basic education). It has been registered, however, an increase in higher education degree holders between 2000 and 2011 (6\% for $11 \%$ of the total stock of emigrants).

Concerning cultural diversity, and besides diversity stemming from migration, the presence, for several centuries, of an ethnic minority - Roma ("ciganos") - must be noticed. Despite the scarcity of data, according to the National Strategy for the Integration of Roma Communities ${ }^{23}$, approved in 2013, it's dimension is estimated between 40000 and 60000 distributed throughout the country.

Regarding particularly to religious diversity, and according to the responses obtained in 2011's Census to the optional question on religion (8 989 849), the religion with the widest presence in Portugal is Roman Catholic (7 281887 , id est about 81\%), followed by other religions, among which Orthodox and Protestant but also Muslim and Jewish religions (whose presence in the territory today corresponding to Portugal dates back to the days leading up to the formation of nationality $)^{24}$. The number of those who

\footnotetext{
${ }^{23}$ Approved by the Council of Ministers on the Resolution No. 25/2013 of 27 March, published in the Diário da República on 17 April 2013. Available in http://www.obcig.acm.gov.pt/

${ }^{24}$ Data available at http://censos.ine.pt. See Censos 2011. Resultados Definitivos-Portugal, p. 530 and Censos 2001. Resultados Definitivos Portugal, p. 538 [12/20/2016]. On this, see Esther Mucznik, "Os Censos, reflexo da liberdade religiosa", in Publico, 01/07/2013. Available at https://www.publico.pt/2013/01/07/opiniao/noticia/os-censos-reflexo-da-liberdade-religiosa-1579808 [12/20/2016]. Mucznik points out to the increasing number of persons declaring to belong to "other religions".
} 
self-declared "no religion" (615 332) increased about $6.84 \%$ when compared to the 2001 Census (342 987) ${ }^{25}$.

The choices made by the destination States concerning the management of migration and integration policies for immigrants have a decisive impact on the configuration of migration flows ${ }^{26}$. The more or less widespread adoption of "multiculturalists measures" from the 60s onwards in the Western world in general reflected a change of approach towards the recognition of cultural diversity, including diversity stemming from migration.

Some indexes - like Multiculturalism Policy Index (MPI) and The Migrant Integration Policy Index (MIPEX) - seek to measure the success of multicultural policies and / or integration of immigrants into host societies.

Although the list is not exhaustive, since several public policies can prove sensibility to the accommodation of cultural pretensions, we can use as an example of relevant public policies in this area the multiculturalist policies adopted by Multiculturalism Policy Index ${ }^{27}$ - which monitors the cultural diversity accommodation policies developed in 21 Western states, over time since 1980, for three types of minorities - national, indigenous and immigrant - thus providing data to compare countries and evaluate policies and their impact. In what concerns immigrant minorities, data relating various policies is taken into account, including the constitutional and infra-constitutional affirmation of multiculturalism, the adoption of multicultural curricula in schools, exceptions for the use of certain garments or dual nationality permission. Portugal has been revealing progressively stronger scores ${ }^{28}$.

Data concerning immigrant integration collected from the Migrant Integration Policy Index (MIPEX), covering several areas, from access to citizenship and antidiscrimination measures to labour market, education and political participation, is also noteworthy. According to data for 2014, Portugal is among the most favourable countries from the point of view of integration of immigrants, getting in 2 nd place (75

\footnotetext{
${ }^{25}$ Considering 8699515 answers to the question, see Censos 2001. Resultados Definitivos Portugal, p. 538.

${ }^{26}$ See Report “Global Trends 2030”, p. $66 \mathrm{ff}$.

${ }^{27}$ http://www.queensu.ca/mcp/index.html [12/20/2016].

${ }^{28} \mathrm{http}: / / \mathrm{www} . q u e e n s u . c a / \mathrm{mcp} / \mathrm{sites} /$ webpublish.queensu.ca.mcpwww/files/files/immigrantminorities/resul ts/ImmigrantMinorities_Table1_SummaryScores_2016.pdf [20/12/2016].
} 
points), on a ranking topped by Sweden, with 3 more points, and above countries such as Canada, Germany or Spain ${ }^{29}$.

The social reactions to this cultural and religious diversity should be reflected upon. As religion is concerned, 2012 data found on the website of the Pew-Templeton Global Religious Future Project do Pew Research Center's Forum on Religion and Public Life put Portugal among the countries with a low level of social hostility on the religion or government restrictions based on religion ${ }^{30}$. As for attitudes towards immigrants and refugees, recently released data placed Portuguese citizens among the less friendly Europeans towards immigration, though showing a more open attitude towards refugees ${ }^{31}$.

Given these data, and in the wider context of the discussion undertaken in this Conference Cycle, what scenarios are configurable?

From the point of demographic view, as we have seen, a scenario that seems probable in 2030 is a slight increase of the fertility index, accompanied by an increase in life expectancy, in a country with a largely aged population ${ }^{32}$.

As for cultural diversity (in a broad sense, encompassing religious diversity) the question remains: in 2030, the Portuguese will affirm their identity as plural? What impact will migration - immigration, but also emigration - have on the issue of setting the "national identity"? Regarding the approach to diversity thus enhanced, we believe a favourable attitude towards foreigners and their integration is still expectable. However, it should be equated to what extent populist and extremist pressures of xenophobic and racist type as those that have been manifesting in Europe also assert in Portugal towards immigrants and refugees.

At the conference of September 28, 2015, cited above, during the intervention of PEDRo DALlari and the debate that followed, the tension and consequent need for harmonization between universal/ global dimensions and local /particular dimensions, were under discussion. The challenge of defining "coexistence requirements" was

\footnotetext{
29 http://www.mipex.eu/key-findings Further developments in that regard in Portugal http://www.mipex.eu/portugal [12/20/2016].

${ }^{30}$ Information obtained from http://www.pewforum.org/2014/01/14/religious-hostilities-reach-six-yearhigh/. [12/20/2016].

${ }^{31}$ This data was released after the Conference Cycle. See

http://www.publico.pt/2016/11/30/sociedade/noticia/portugal-entre-os-paises-que-mais-se-opoem-aacolher-imigrantes-1753095 [12/20/2016]. See also http://asp.ics.ul.pt/

${ }^{32}$ For different demographic scenarios, see Projeções 2030 e o Futuro, Coord. Maria Filomena Mendes e Maria João Valente Rosa, FFMS, 2012, available at https://www.ffms.pt/upload/docs/cenariosdemograficos-para-2030_Ibv9dZ84FEmBVJ1-J_1z9w.pdf
} 
pointed out, as well as need to discuss legitimacy issues concerning the establishment of a "common order" in which human rights play a decisive role. Legitimacy issues should, however, be discussed in the wider context of discussion on the future of democracy ${ }^{33}$.

Present and future democracies must know how to manage the tension resulting from diversity, namely cultural diversity, and find living arrangements able to accommodate differences without compromising equality. Extremist and populist movements, as well as racist and xenophobic movements, notably targeting immigrants and refugees, pose a challenge to current democracies, at State but also supra-State level, e.g. at EU level. This, namely the issue of populism as a product of globalization, was, for example, addressed by DURÃO BARROSO'S on January $14^{\text {th }} 2016$ at the conference on The global governance in a polycentric world: the challenges of the European Union ${ }^{34}$.

Recent movements of refugees to Europe - whose origins and multiple causes were much discussed throughout this Conference Cycle and were addressed by ANTÓNIO GUTERRES in his conference on January $25^{\text {th }} 2016^{35}$ - may help illustrate the dimension of opportunity inherent to them (not only, but also, at economic level, due to low fertility rates and aged labour population in Europe).

This allows us to illustrate the ambivalence of the glances towards "the Other", "the Different", while at the same time reveals the need to articulate cultural dimensions - the perception of the cultural difference of "the Other" - with structural inequality dimensions, namely socio-economic ones. Both are relevant to understanding the phenomena of exclusion. Returning to the words of ANTÓNIO GUTERRES in the abovementioned Conference - which, although spoken in relation to Europe, can also serve as theme for reflection within States increasingly multicultural (in a descriptive sense) - it is necessary to invest in creating conditions for a better relationship between different communities.

Even though acknowledgement and respect for diversity should not be seen as a threat, concerns towards the guarantee of cohesion, which is also important for

\footnotetext{
${ }^{33}$ See Sofia Oliveira et al., on this issue. The future of democracy was precisely in discussion at the conference that took place in November $20^{\text {th }} 2015$, to which we refer. For video-audio record, see http://www.serralves.pt/pt/actividades/ciclo-de-conferencias-tendencias-globais-2030-os-futuros-deportugal/

34 To which we refer. For video-audio record, see http://www.serralves.pt/pt/actividades/ciclo-deconferencias-tendencias-globais-2030-os-futuros-de-portugal/

${ }^{35}$ To which we refer. For video-audio record, see http://www.serralves.pt/pt/actividades/ciclo-deconferencias-tendencias-globais-2030-os-futuros-de-portugal/
} 
democracies, necessarily arise. The tension between diversity and cohesion must be managed. Relevant political and legal recognition issues are at stake ${ }^{36}$.

At last, and because many are the variety of contexts, the positioning of Portugal in external diversity contexts, namely in European and the Portuguese-speaking contexts, deserves more thought, bearing in mind the disintegration scenarios that have been discussed throughout the Conference Cycle and whose spectrum, in one way or another, hangs over. Having in mind the need to manage diversity in different political and economic levels, the question of whether and to what extent economic, financial, social, but also political, European crisis - from Brexit to the claims of "small homelands" ${ }^{37}$, as illustrated inter alia the issue of autonomy for Catalonia - will impact Portugal, must be discussed.

It is still about the (so-called) crisis of the Nation-State, threatened internally and externally, repeatedly spoken about over the Conference Cycle and also in its final conference on February ${ }^{38}$, and the possible ways for overcoming them ${ }^{39}$. If the existence of States is not at issue, the need for State's role reconfiguration most probably is.

In short, and calling on the words of RUI TAVARES at the above-mentioned session of February $2016^{40}$, a challenge for Portugal seems to be the one of properly managing "multiple identities".

Article received on December 21, 2016 | Accepted December 30, 2016

\footnotetext{
${ }^{36}$ On this, see inter alia ROBERTA MEDDA-WINDISCHER, Old and new minorities: reconciling diversity and cohesion. A human rights model for minority integration, Baden-Baden, 2009.

${ }^{37}$ We refer to the expression used by Adriano Moreira, "As pequenas pátrias", in Diário de Notícias, 12/23/2015, available at http://www.dn.pt/opiniao/opiniao-dn/adriano-moreira/interior/as-pequenaspatrias-4949799.html [10/31/2016]

38 To which we refer. For video-audio record, see http://www.serralves.pt/pt/actividades/ciclo-deconferencias-tendencias-globais-2030-os-futuros-de-portugal/

39 Among considerable literature on this issue, see inter alia The Oxford handbook of transformations of the state, Oxford, Oxford University Press, 2015.

${ }^{40}$ For video-audio record, see http://www.serralves.pt/pt/actividades/ciclo-de-conferencias-tendenciasglobais-2030-os-futuros-de-portugal/
} 